\title{
PENGEMBANGAN MEDIA PEMBELAJARAN BERBASIS MOBILE LEARNING TEKNIK DASAR DAN PERATURAN PERMAINAN FUTSAL
}

\author{
Andryas Yuniarto ${ }^{1}$, Supriyadi ${ }^{2}$ ), I Nengah Sudjana ${ }^{3}$ ) \\ Ilmu Keolahragaan Universitas Negeri Malang \\ Email: 1a.yuniarto16@gmail.com \\ supriyadi0um@gmail.com \\ 3nengah.sudjana.fik@um.ac.id
}

\begin{abstract}
ABSTRAK
Tujuan dari penelitian dan pengembangan ini yaitu mengembangkan media pembelajaran permainan futsal berbasis mobile learning (buku digital) sehingga peserta belajar memperoleh media ajar baru dan lebih semangat dalam mempelajari permainan futsal. Teknik analisis data yang digunakan dalam penelitian pengembangan ini adalah teknik analisis deskriptif dengan persentase. Teknik ini digunakan untuk menganalisis data yang diperoleh dari hasil penyebaran angket/kuesioner. Berdasarkan hasil analisis data uji coba kelompok kecil diperoleh persentase rata-rata 85,28\% dan pada uji coba kelompok besar diperoleh persentase rata-rata $91,05 \%$ sehingga memenuhi kriteria valid dengan isi materi yang mencakup teknik dasar permainan futsal dan peraturan permainan resmi futsal dari FIFA berbahasa Indonesia. Spesifikasi produk yang dihasilkan yaitu berbentuk file .epub berukuran $37,5 \mathrm{MB}$ yang dapat diakses melalui aplikasi (.epub reader) di smartphone yang dapat diakses kapan dan dimana saja.
\end{abstract}

Kata Kunci: Media pembelajaran, buku digital, teknik dasar, permainan futsal

\begin{abstract}
The purpose of this research and development is to develop a learning media for futsal games based on mobile learning (digital books) so that participants learn to acquire new teaching media and be more enthusiastic in learning futsal games. The data analysis technique used in this development research is a descriptive analysis technique with percentages. This technique is used to analyze data obtained from the results of questionnaires / questionnaires. Based on the results of the data analysis of small group trials obtained an average percentage of $85.28 \%$ and in the large group trials obtained an average percentage of $91.05 \%$ so that it meets the valid criteria with the content of the material which includes basic techniques of futsal games and the rules of official futsal games from FIFA in Indonesian. The product specifications are in the form of a 37.5MB .epub file that can be accessed through an application (. Reader reader) on a smartphone that can be accessed anytime and anywhere.
\end{abstract}

Keywords:Learning media, digital book, basic techniques, futsal 


\section{PENDAHULUAN}

Olahraga adalah suatu kegiatan yang hampir semua orang pernah melakukan sepanjang hidupnya, baik yang dilakukan secara profesional dengan latihan dan jadwal pertandingan yang ketat, maupun olahraga yang dilakukan sekedar sebagai hobi pengisi waktu luang. Banyak sekali cabang olahraga yang ada saat ini. Tapi, hanya beberapa yang cabang olahraga yang populer atau paling banyak dilakukan. Seperti sepakbola dan futsal contohnya. Dua cabang olahraga ini menjadi olahraga yang cukup populer untuk saat ini. Sepakbola dan futsal tidak hanya sebagai olahraga untuk kejuaraan, tetapi juga bisa untuk sekedar pengisi waktu luang.

Membahas tentang futsal, olahraga yang diadopsi dari sepak bola ini pertama kali muncul dan dipopulerkan di Uruguay oleh Juan Carlos Ceriani. Kata futsal sendiri berasal dari gabungan 2 kata bahasa spanyol atau portugis, yaitu futbol (sepakbola) dan sala (ruangan). Yang berarti sepakbola dalam ruangan. Pemain futsal hanya 5 orang termasuk seorang penjaga gawang. Biasanya ada 2 jenis lapangan futsal yang dipakai, yaitu lapangan dengan lantai parkit atau kayu dan lapangan dengan rumput sintetis. Lapangan dengan lantai parkit atau kayu merupakan standar minimal untuk melakukan pertandingan nasional dan internasional, sementara lapangan dengan rumput sintetis biasanya hanya untuk sekedar hobi atau pengisi waktu luang.

Futsal masuk ke Indonesia berkisaran antara tahun 1998-1999 dan masyarakat mulai mengenal dengan baik pada tahun 2000-an. Pada saat itulah futsal mulai berkembang dengan pesat diikuti lahirnya banyak sekolah-sekolah futsal di Indonesia. Kemudian, pada tahun 2002 Indonesia diminta oleh AFC untuk menggelar kejuaraan Piala Asia (De Padua, dkk, 2015). Secara resmi, badan sepak bola dunia FIFA menyebutkan futsal pertama kali dimainkan di Montevideo, Uruguay, tahun 1930. Futsal adalah permainan sejenis sepakbola yang dimainkan dalam lapangan yang berukuran lebih kecil. Permainan ini dimainkan oleh 10 orang (masingmasing tim 5 orang) saja, dan maksimal 9 pemain cadangan. Menggunakan bola yang lebih kecil dan lebih berat daripada yang digunakan dalam sepak bola. Gawang yang digunakan dalam futsal juga lebih kecil De Padua, dkk yang dikutip (Suwasono dan Irawan Dwi, 2017).

Menurut (Dian Ika Purba Ratna Wijayanti dan B. M. Wara Kushartanti, 2014) bentuk pembelajaran yang disederhanakan dan festival/kompetisi dijalankan sebagai alat untuk mengembangkan teknik dan keterampilan dasar. Bola harus menjadi titik sentral dari aktivitas dengan banyak variasi dan kegembiraan. Karena setiap pemain futsal harus mempunyai keterampilan bermain yang baik. Keterampilan dasar bermain futsal pada dasarnya tidak jauh berbeda dengan sepakbola. Keterampilan

Andryas Yuniarto. Pengembangan Media Pembelajaran Berbasis Mobile Learning Teknik Dasar Dan Peraturan Permainan Futsal

52 | Page 
http://ejurnal.budiutomomalang.ac.id/index.php/ipjok

Jp.jok (Jurnal Pendidikan. Jasmani , Olahraga dan Kesehatan)
Volume 2, Nomor 1, Nov 2018

P-ISSN 2613-9421

E-ISSN 2654-8003

dasar tersebut berupa keterampilan dengan bola maupun tanpa bola. Maka oleh sebab itu pembelajaran yang dilakukan harus menarik apalagi bisa ditambah dengan penggunaan media pembelajaran yang sesuai.

Selama perkuliahan futsal, penyampaian materi diberikan diawal perkuliahan dengan memberikan modul yang berisi materi tentang futsal selama 1 semester perkuliahan. Kemudian dalam setiap pertemuan, pengajar memberi materi secara langsung melalui lisan di lapangan futsal sebelum melakukan praktik. Metode pengajaran tersebut secara tidak langsung membuat mahasiswa akan mencari tahu sendiri materi tambahan tentang futsal. Mahasiswa bisa memanfaatkan perkembangan ilmu pengetahuan dan teknologi (IPTEK) yang saat ini sangat pesat berkembang. Perkembangan IPTEK tersebut sedikit demi sedikit mulai merubah proses penyampaian materi dalam perkuliahan.

Berkembangnya IPTEK pada saat ini mengakibatkan media belajar yang digunakan oleh peserta belajarpun semakin baik, seperti halnya yang telah kita ketahui bersama banyak media ajar yang bisa digunakan seperti : media audio (radio, tape-recorder), media audio-visual (televisi, video,internet, film, dan lain-lain) dan media cetak (buku ajar, modul, dan lembar kerja bagi peserta belajar), namun kini smartphone juga merupakan salah satu media ajar yang bisa digunakan oleh peserta belajar untuk mendapatkan informasi yang diinginkan.

Media merupakan alat atau cara yang digunakan sebagai perantara untuk menyampaikan informasi atau pesan agar dapat diterima oleh penerima informasi sepenuhnya (Dwiyogo, 2010). Media pembelajaran yang menarik akan lebih menarik minat, perhatian, dan pemahaman dari seseorang terhadap informasi yang disajikan. Berdasarkan pendapat diatas dapat disimpulkan bahwa media merupakan suatu alat yang membantu dalam proses belajar mengajar agar tujuan belajar sendiri bisa tersampaikan, hal ini akan lebih efektif lagi jika media yang digunakan memliki nilai kemenarikan baik dari bentuk, tampilan atau cara penggunaanya. Materi pembelajaran dan sistem penyampaian selalu berkembang, sama halnya seperti perkembangan teknologi yang ada saat ini, terutama dalam penggunaan handphone yang sudah menjadi suatu media multifungsi dalam kehidupan manusia saat ini.

Beberapa hal yang menjadi pertimbangan peneliti mengambil mobile learningsebagai media ajar adalah pemanfaatan teknologi informasi dan komunikasi di dalam dunia pendidikan terus berkembang dalam berbagai strategi dan pola. Mobile learning merupakan salah satu bentuk pembelajaran yang memanfaatkan media elektronik dan media digital dimana media ini dikembangkan khusus untuk pemanfaatan perangkat dan teknologi komunikasi bergerak. Mobile learningdapat dibaca pada komputer (AZARDI, Calibre, Plugin firefox, plugin google chrome), android (fbreader, 
Ideal Group Reader, Skoob EPUB Reader, Ultimate Reader), Ios (ireader), Kobo eRader, blackberry playbook, barnes and noble nook, sony reader, dan berbagai perangkat lainnya dengan konsep mobile learningyang praktis dibawa kemana-mana, dan isi yang menarik.

Tingkat penggunaan yang relatif mudah, tingkat perkembangan perangkat bergerak yang sangat tinggi, dan harga perangkat yang semakin terjangkau dibandingkan perangkat komputer personal, merupakan faktor pendorong yang semakin memperbanyak kesempatan penggunaan atau penerapan mobile learningsebagai sebuah kecenderungan baru dalam belajar, yang membentuk suatu pemikiran baru dimana pembelajaran bisa dilakukan dimanapun dan kapanpun. Banyak sekali produk-produk yang memiliki kelebihan-kelebihan tersendiri seperti berbagai aplikasi yang bisa di install dalam handphone kita mulai dari yang memiliki unsur teknologi, seni, permainan, agama, bahkan pendidikan. Hal ini dikarenakan handphone tersebut sudah memiliki kemampuan lebih dalam memproses informasi yang didapat dan memiliki teknologi yang lebih canggih, handphoneini sering kita kenal dengan sebutan smartphoneatau telepon pintar. Sudah banyak mahasiswa yang memiliki smartphone untuk membantu mahasiswa dalam berkomunikasi, mencari hiburan ataupun mendapatkan informasi.

Smartphoneadalah telepon yang memiliki kemampuan seperti komputer, biasanya memiliki layar yang besar dan sistem operasinya mampu menjalankan tujuan aplikasi-aplikasi yang umum. Smartphoneyang beredar di kalangan masyarakat memiliki beberapa jenis seperti Blackberry, Windowsphone, Iphone, dan Android. Smartphonedapat berfungsi seperti layaknya komputer dengan menawarkan fitur-fitur seperti Personal Digital Assistant(PDA), akses internet, e-mail, dan Global Positioning System(GPS). Smartphonejuga memiliki fungsi-fungsi lainnya seperti kamera, video, mp3 players, sama seperti telepon genggam biasa. Dengan kata lain, smartphonedapat dikategorikan sebagai mini computer yang memiliki banyak fungsi dan penggunanya dapat menggunakan kapanpun dan dimanapun.

Menurut (Ally, 2009), nirkabel, mobile, portable, perangkat genggam perlahan-lahan sedang berkembang dan menganekaragamkan pendidikan di berbagai sektor, baik di negara maju maupun negara yang sedang berkembang. Menurut situs Mobo Market, yang ternama di Indonesia, pengguna smartphone di 39 negara di dunia dan 13 di antaranya yaitu negara-negara di Asia, termasuk Indonesia. Berdasarkan penjelasan tersebut penggunaan smartphonesangat popular dan familiar di Negara kita, dan tentunya akan terus berkembang seiring peradaban manusia yang semakin maju. 
$\underline{\text { http://ejurnal.budiutomomalang.ac.id/index.php/ipjok }}$

Jp.jok (Jurnal Pendidikan. Jasmani , Olahraga dan Kesehatan)
Volume 2, Nomor 1, Nov 2018

P-ISSN 2613-9421

E-ISSN 2654-8003

Dari beberapa teori tentang perkembangan IPTEK dan penggunaan mobile learning sebagai media pembelajaran tersebut, menjadi bahan pertimbangan bagi peneliti untuk mengambil mobile learning sebagai media ajar. Media mobile learning akan sangat cocok sebagai media pembelajaran saat ini yang sejalan dengan perkembangan perangkat smartphone yang sangat pesat dibandingkan dengan Personal Computer $(P C)$, yang kemudian membentu suatu pemikiran baru yaitu pembelajaran dapat dilakukan kapan pun dan dimana pun.

\section{METODE}

Model pengembangan yang digunakan di dalam penelitian ini mengacu pada model pengembangan (research and development) dari (Borg dan Gall, 1983) yang terdiri dari sepuluh langkah. Menurut (Ardhana, 2002), prosedur pelaksanaan penelitian pengembangan bukan merupakan langkahlangkah yang baku yang harus diikuti secara kaku, setiap pengembang tentu saja dapat memilih dan menentukan langkah-langkah yang paling tepat bagi dirinya berdasarkan kondisi khusus yang dihadapinya dalam proses pengembangan. Oleh karena itu penelitian ini dilaksanakan pada salah satu program studi yang ada di Fakultas Ilmu Keolahragaan, Universitas Negeri Malang, yaitu program studi S1 Ilmu Keolahragaan dengan subyek berjumlah 30 mahasiswa, maka langkah ke 8 sampai 10 tidak dilaksanakan. Peneliti melakukan modifikasi dan hanya menggunakan 7 langkah pengembangan, yaitu: (1) Riset dan pengumpulan informasi dalam melakukan penelitian awal atau analisis kebutuhan (needassesment) dengan kuesioner yang ditujukan kepada mahasiswa Jurusan Ilmu Keolahragaan, (2) Pengembangan rancangan produk, (3) Evaluasi para ahli dengan menggunakan satu ahli media pembelajaran, satu ahli pembelajaran futsal, dan satu ahli perwasitan futsalyang menghasilkan produk awal, (4) Revisi rancangan produk berdasarkan evaluasi para ahli (hasil rancangan produk berupa produk awal) dan uji coba lapangan pada kelompok kecil, (5) Revisi hasil dari uji coba lapangan pada kelompok kecil, (6) Uji coba lapangan pada kelompok besar, (7) Revisi dari hasil uji coba lapangan pada kelompok besar, (8)Produk akhir.

Subyek yang terlibat dalam penelitian dan pengembangan ini adalah sebagai berikut: (a) Subyek sebagai penelitian awal (analisis kebutuhan) dilakukan dengan menyebarkan angket kepada 30 mahasiswa Jurusan Ilmu Keolahragaan, (b) Subyek evaluasi ahli terdiri dari seorang ahli media pembelajaran, seorang ahli pembelajaran futsal, dan seorang ahli perwasitan futsal, (c) Subyek uji coba (kelompok kecil) adalah 10 mahasiswa Jurusan Ilmu Keolahragaan, (d) Subyek uji lapangan (kelompok besar) adalahadalah 30 mahasiswa Jurusan Ilmu Keolahragaan. 
Jenis data yang dihasilkan berupa data kualitatif dan data kuantitatif. Pengambilan data kuantitatif diperoleh berdasarkan pengambilan data melalui penelitian awal berupa angket untuk 30 mahasiswa Jurusan Ilmu Keolahragaan dan uji coba kelompok. Sedangkan data kualitatif diperoleh dari tinjauan para ahli yaitu 1 orang ahli media pembelajaran, 1 ahli pembelajaran futsal, dan 1 orang ahli perwasitan futsal terhadap produk yang telah dibuat berupa pengembangan media pembelajaran buku digital permainan futsal.

\section{HASIL DAN PEMBAHASAN \\ Hasil Analisis Kebutuhan (Need Assessment)}

Berdasarkan survei awal mengenai pengguna smartphone yang ditujukan kepada mahasiswa Jurusan Ilmu Keolahragaan diperoleh sebanyak $73,33 \%$ sebagai pengguna smartphoneberbasis android dan sebanyak 26,67\% sebagai pengguna handphone selain android. Kemudian hasil dari pengisian angket analisis kebutuhan terhadap 30 mahasiswa Jurusan Ilmu Keolahragaan diperoleh sebanyak 73,33\% mahasiswa masih kurang menguasasi/lupa teknik dasar dan peraturan permainan futsal, 76,67\% mahasiswa sebagai pengguna handphone lebih dari 12 jam dalam sehari, $56,67 \%$ mahasiswa menggunakan handphone lebih dari 1 jam untuk belajar, dan sebesar $100 \%$ mahasiswa perlu dan setuju dengan dikembangkan media pembelajaran mobile learning tentangteknik-teknik dasar permainan futsal dan peraturan permainan futsal.

\section{Analisis dari Evaluasi Ahli}

Berdasarkan hasil evaluasi dari ahli media pembelajaran mengenai pengembangan media pembelajaran berupa buku digital tentang permainan futsal untuk mahasiswa Jurusan Ilmu Keolahragaan dapat diketahui bahwa dari indikator kejelasan, mendapatkan skor 28 dari skor maksimal 30. Ada 2 aspek yang dinilai masih memerlukan revisi pada indikator kejelasan. Yaitu kejelasan pada jenis (font) di halaman pembuka dan gambar posisi kaki saat melakukan passing futsal. Dari indikator kemenarikan, diketahui mendapatkan skor 31 dari skor maksimal 32. Ada 1 aspek yang dinilai masih memerlukan revisi yaitu pada jenis (font) yang digunakan pada halaman pembuka dalam media buku digital ini. Dan dari indikator kesesuaian dan kebermanfaatan, keduanya mendapatkan skor maksimal yaitu 4 dan 2. Jadi, dapat diketahui bahwa produk berupa buku digital tersebut masih perlu adanya perubahan sehingga dapat lebih menarik dan tujuan penelitian dapat tercapai.

Saran-saran ahli media pembelajaran mengenai pembelajaran berupa buku digital tentang teknik dasar dan peraturan permainan futsal untuk

Andryas Yuniarto. Pengembangan Media Pembelajaran Berbasis Mobile Learning Teknik Dasar Dan Peraturan Permainan Futsal 
http://ejurnal.budiutomomalang.ac.id/index.php/jpjok

Jp.jok (Jurnal Pendidikan. Jasmani , Olahraga dan Kesehatan)
Volume 2, Nomor 1, Nov 2018

P-ISSN 2613-9421

E-ISSN 2654-8003

mahasiswa jurusan IK, (1) halaman pembuka (cover) perlu adanya revisi, terkait dengan pemilihan warna pada backgorund, huruf, dan ukuran font antara heading dan sub-heading. (2) ditambahkan identitas penyusun (nama dan NIM), (3) ditambahkan serangkain foto/video gerakan pada materi teknik dasar futsal (passing, controlling, dribbling, shooting), (4) perlu adanya pembeda antara judul dan subjudul dengan cara dibedakan pada ukuran font atau menggunakan bold/italic, (5) perlu ditambahkan bullet/numbering sebagai penanda tahapan/urutan dan penjelasan, (6) perlu adanya perbaikan dalam penggunaan bahasa Indonesia dan bahasa Inggris yang baik dan benar, (7) tambahkan foto/video posisi wasit futsal saat di lapangan, (8) tambahkan CV penulis pada akhir produk.

Berdasarkan hasil evaluasi ahli pembelajaran futsal mengenai pengembangan media pembelajaran berupa buku digital tentang permainan futsal untuk mahasiswa Jurusan Ilmu Keolahragaan oleh ahli pembelajaran futsal dapat diketahui bahwa keempat indikator dalam kuesioner/angket, semuanya mendapatkan skor maksimal. Indikator kejelasan mendapatkan skor 2, indikator kesesuaian mendapatkan skor 6, indikator kebermanfaatan mendapatkan skor 2, dan indikator kelengkapan mendapatkan skor 6. Jadi, dapat diketahui bahwa cakupan materi sudah sesuai dan lengkap.

Saran-saran yang diberikan oleh ahli pembelajaran futsal terhadap hasil pengembangan media pembelajaran berupa buku digital tentang permainan futsal untuk mahasiswa jurusan Ilmu Keolahragaan yaitu, (1) Penjelasan pada setiap gambar teknik dasar futsal disempurnakan, (2) Urutan gambar teknik dasar dibuat secara sistematis, (3) Tambahkan materi tentang sejarah olahraga futsal pada awal produk, dan (4) Lengkapi identitas pada cover.

Berdasarkan hasil evaluasi ahli perwasitan futsal mengenai pengembangan media pembelajaran berupa buku digital tentang permainan futsal untuk mahasiswa Jurusan Ilmu Keolahragaan oleh ahli perwasitan futsal dapat diketahui bahwa ketiga indikator yang ada dalam kuesioner/angket, semuanya mendapatkan skor maksimal. Indikator kesesuaian mendapatkan skor 34, indikator kebermanfaatan mendapatkan skor 5, dan indikator kejelasan mendapatkan skor 1. Jadi, dapat diketahui bahwa gambar, penjelasan, dan istilah dari materi peraturan permainan futsal dalam media pembelajaran buku digital ini sudah sesuai standar FIFA dan sesuai untuk media pembelajaran bagi mahasiswa Jurusan Ilmu Keolahragaan ataupun bagi wasit-wasit futsal.

Saran-saran yang diberikan oleh ahli perwasitan futsal terhadap hasil pengembangan media pembelajaran buku digital tentang permainan futsal untuk mahasiswa jurusan Ilmu Keolahragaan yaitu, penggunaan atau penerjemahan dari bahasa inggris ke bahasa Indonesia perlu dicermati dan 
dikoreksi kembali serta hasil pengembangan produk buku digital tentang teknik dasar dan peraturan permainan ini bisa dikonversi ke bentuk PDF atau file sejenisnya agar tidak hanya digunakan oleh mahasiswa jurusan IK saja tetapi dapat digunakan oleh pemain dan wasit futsal.

\section{Analisis Data Uji Kelompok Kecil}

Data hasil uji coba kelompok kecil yang dilakukan di Fakultas Ilmu Keolahragaan kepada mahasiswa Jurusan Ilmu Keolahragaan dengan jumlah 10 orang dengan 69 butir pertanyaan, dengan terdapat beberapa indikator yaitu kejelasan, kemenarikan, kemudahan, kesesuaian, dan kebermanfaatan, diperoleh hasil sebesar $85.28 \%$ dan masuk dalam kategori baik. Namun, terdapat kekurangan dalam kemenarikan desain pada beberapa bagian dari media pembelajaran ini yaitu desain tulisan pada cover. Oleh karena itu, berdasarkan pada hasil tersebut, produk media pembelajaran mobile learning permainan futsal untuk mahasiswa Jurusan Ilmu Keolahragaan masih perlu direvisi kembali agar dapat digunakan dengan baik oleh mahasiswa Jurusan Ilmu Keolahragaan Universitas Negeri Malang.

\section{Tabel 1. Data Hasil Uji Coba Kelompok Kecil}

\begin{tabular}{llcccc}
\hline No. & \multicolumn{1}{c}{ Aspek } & $\begin{array}{c}\text { Skor } \\
\text { Hasil }\end{array}$ & $\begin{array}{c}\text { Skor } \\
\text { Maksimal }\end{array}$ & Persentase(\%) & Keterangan \\
\hline 1. & Kejelasan & 1135 & 1320 & $85.98 \%$ & Baik \\
2. & Kemenarikan & 1009 & 1200 & $84.08 \%$ & Baik \\
3. & Kemudahan & 106 & 120 & $88.33 \%$ & Baik \\
4. & Kesesuaian & 69 & 80 & $86.25 \%$ & Baik \\
5. & Kebermanfaatan & 35 & 40 & $87.5 \%$ & Baik \\
\hline & Total & $\mathbf{2 3 5 4}$ & $\mathbf{2 7 6 0}$ & $\mathbf{8 5 . 2 8 \%}$ & Baik \\
\hline
\end{tabular}

\section{Analisis Data Uji Kelompok Besar}

Data hasil uji coba kelompok besar yang dilakukan di Champions Futsal Tlogomas kepada mahasiswa Jurusan Ilmu Keolahragaan dengan jumlah 30 orang dengan 69 butir pertanyaan, dengan terdapat beberapa indikator yaitu kejelasan, kemenarikan, kemudahan, kesesuaian, dan kebermanfaatan, diperoleh hasil sebesar $91.05 \%$ dan masuk dalam kategori baik.

Tabel 2. Data Hasil Uji Coba Kelompok Besar

\begin{tabular}{lccccc}
\hline No. & Aspek & $\begin{array}{c}\text { Skor } \\
\text { Hasil }\end{array}$ & $\begin{array}{c}\text { Skor } \\
\text { Maksimal }\end{array}$ & Persentase(\%) & Keterangan \\
\hline 1. & Kejelasan & 3600 & 3960 & $90.90 \%$ & Baik \\
2. & Kemenarikan & 3280 & 3600 & $91.11 \%$ & Baik \\
\hline
\end{tabular}

Andryas Yuniarto. Pengembangan Media Pembelajaran Berbasis Mobile Learning Teknik Dasar Dan Peraturan Permainan Futsal

58| Page 
http://ejurnal.budiutomomalang.ac.id/index.php/ipjok

Jp.jok (Jurnal Pendidikan. Jasmani , Olahraga dan Kesehatan)
Volume 2, Nomor 1, Nov 2018

P-ISSN 2613-9421

E-ISSN 2654-8003

\begin{tabular}{llcccc}
\hline 3. & Kemudahan & 340 & 360 & $94.44 \%$ & Baik \\
4. & Kesesuaian & 219 & 240 & $91.25 \%$ & Baik \\
5. & Kebermanfaatan & 109 & 120 & $90.83 \%$ & Baik \\
\hline & Total & $\mathbf{7 5 3 9}$ & $\mathbf{8 2 8 0}$ & $\mathbf{9 1 . 0 5 \%}$ & Baik \\
\hline
\end{tabular}

Hasil akhir dari penelitian pengembangan ini adalah berupa produk media pembelajaran buku digital tentang permainan futsal untuk mahasiswa jurusan Ilmu Keolahragaan, Fakultas Ilmu Keolahragaan, Universitas Negeri Malang. Produk ini menggunakan metode pengembangan dan mengacu pada rancangan penelitian pada model pengembangan (research and development) Borg and Gall. Kelebihan dari produk ini adalah (1) Materi tentang teknik dasar dan peraturan permainan futsal (law of the game) dikemas dalam satu bentuk buku digital yang simple dan menarik sehinga bisa menarik minat pembaca dan memiliki unsur hiburan, (2) Materi tentang teknik dasar futsal diambil dari buku tentang teknik dasar futsal dan dilengkapi dengan gambar langsung dari peneliti saat mempraktikkan teknik dasar futsal serta dilengkapi dengan video yang dirujuk langsung dari FIFA, (3) Materi tentang peraturan permainan (law of the game) futsal dirujuk langsung dari peraturan permainan futsal terbaru (2014/2015) yang diterjemahkan ke dalam Bahasa Indonesia dan dilengkapi dengan gambar contoh di dalamnya serta video contoh tentang pelanggaran pada peraturan permainan futsal, (4) Media buku digital ini dapat digunakan sebagai media pembelajaran mandiri, (5) Media buku digital ini praktis, dapat dibawa kemana-mana karena bisa langsung diakses melalui smartphone, (6) Media buku digital ini berperan sebagai pelengkap, penguat, dan pengingat (reminder).

Kelebihan dari produk mobile learning tersebut sudah sesuai dengan teori tentang manfaat media pembelajaran berbasis mobile learning yang dikemukakan oleh (Dwiyogo, 2010) yaitu: (a) Media pembelajaran menarik dan memperbesar perhatian anak didik terhadap materi pengajaran yang disajikan, (b) Media pembelajaran mengatasi perbedaan pengalaman belajar berdasarkan latar belakang sosial ekonomi dari anak didik, (c) Media pembelajaran membantu memberikan pengalaman belajar yang sulit diperoleh dengan cara lain, (d) Media pembelajaran dapat menumbuhkan kemampuan berusaha sendiri berdasarkan pengalaman dan kenyataan, (e) Dengan menggunakan media pembelajaran secara tepat dan bervariasi dapat diatasi sikap pasif anak didik, (f) Media pembelajaran dapat menimbulkan kegairahan belajar, (g) Media pembelajaran memungkinkan interaksi yang lebih langsung antara anak didik dengan lingkungan dan kenyataan, (h) Media pembelajaran memungkinkan anak didik belajar sendiri menurut kemampuan dan minatnya. 
Hasil pengembangan ini adalah pengembangan buku digital tentang permainan futsal untuk mahasiswa jurusan Ilmu Keolahragaan. Hasil pengembangannya yaitu: (1) Buku digital yang dikembangkan merupakan media pembelajaran yang dibuat dalam format .epub yang bisa terbaca oleh smartphone yang memiliki epub reader di dalamnya, (2) Buku digital ini berisi tentang teknik dasar futsal (gambar dan penjelasan), peraturan permainan (law of the game) futsal dalam bentuk Bahasa Indonesia yang disertai dengan beberapa signal wasit futsal yang diharapkan dapat membantu mahasiswa dalam memahami materi, (3) Gambar dalam materi teknik dasar futsal adalah gambar dari peneliti yang sedang mempraktikkan teknik dasar futsal yang dimaksudkan agar mahasiswa lebih mudah dapat memahami dan mempraktikkannya.

Dalam proses pengembangan media pembelajaran dalam bentuk buku digital tentang permainan futsal ini terdapat beberapa hal yang perlu direvisi. Revisi dilakukan berdasarkan saran dari ahli media pembelajaran, ahli pembelajaran futsal, ahli perwasitan futsal, uji coba kelompok kecil, dan uji coba kelompok besar.

Berdasarkan data yang diperoleh dari hasil evaluasi ahli terdapat beberapa revisi yang harus dilakukan pada produk yang dikembangkan antara lain: (1) Halaman pembuka (cover) perlu adanya revisi, terkait dengan pemilihan warna pada backgorund, huruf, dan ukuran font antara heading dan sub-heading. (2) Tambahkan identitas penyusun (nama), (3) Tambahkan materi tentang sejarah olahraga futsal pada awal produk, (4) Tambahkan serangkain foto/video gerakan pada materi teknik dasar futsal (passing, controlling, dribbling, shooting) disertai penjelasan pada setiap gambar teknik dasar futsal disempurnakan, (5) Urutan gambar teknik dasar dibuat secara sistematis, (6) Perlu adanya pembeda antara judul dan subjudul dengan cara dibedakan pada ukuran font atau menggunakan bold/italic, (7) Perlu ditambahkan bullet/numbering sebagai penanda tahapan/urutan dan penjelasan, (8) Perlu adanya perbaikan dalam penggunaan bahasa Indonesia dan bahasa Inggris yang baik dan benar, (9) Tambahkan foto/video posisi wasit futsal saat di lapangan, (10) Tambahkan CV penulis pada akhir produk. Setelah itu, hasil revisi tersebut diujicobakan pada uji coba kelompok kecil, diperoleh hasil pada bagian: (1) Terdapat kekurangan pada kejelasan gambar materi peraturan permainan futsal dan penambahan keterangan pada gambar.

Kelemahan dari produk ini adalah media buku digital permainan futsal ini hanya sampai tersusun pada tingkat produk, belum sampai pada tingkat efektifitas produk. Produk ini hanya berperan sebagai pelengkap, penguat, dan pengingat (reminder) dari praktik teknik dasar permainan futsal dan peraturan permainan (law of the game) futsal. Produk ini hanya bisa digunakan untuk smartphone yang telah memiliki aplikasi epub reader di

Andryas Yuniarto. Pengembangan Media Pembelajaran Berbasis Mobile Learning Teknik Dasar Dan Peraturan Permainan Futsal

60 | Page 
dalamnya. Produk ini memiliki ukuran file sebesar $36 \mathrm{MB}$, sehingga untuk smartphone yang memiliki kapasitas RAM yang kecil (kurang dari 1GB) akan kesulitan untuk membaca file ini.

Hasil penelitian ini memperkuat hasil penelitian tentang media pembelajaran berbasis mobile learning yang telah dilakukan oleh peneliti lain diantaranya (Iwan Koerniawan dan Siti Kholifah, 2016), (Dasmo dkk, 2017), (Muhammad Saefi, dkk, 2017), Muhamad Taufik, 2017), (Ramadhana Agung Pratama, dkk. 2018).

\section{SIMPULAN}

Pengembangan media pembelajaran permainan futsal berbasis mobile learning untuk mahasiswa Jurusan Ilmu Keolahragaan ini dapat membantu mahasiswa lebih semangat dan antusias dalam mempelajari materi permainan futsal yang berisi tentang teknik dasar dan peraturan permainan futsal.

Pada bagian ini peneliti mengemukakan beberapa saran yang berhubungan dengan media pembelajaran buku digital tentang teknik dasar dan peraturan permainan (law of the game) futsal yang dikembangkan. Adapun saran-saran yang dikemukakan meliputi saran pemanfaatan dan saran pengembangan lebih lanjut.

\section{DAFTAR PUSTAKA}

Ally, M.2009. Mobile Learning Transforming the Delivery of Education and Training. Athabasca University : AU Press

Ardhana, W. 2002. Konsep Penelitian Pengembangan dalam Bidang Pendidikan dan Pembelajaran. Malang: Universitas Negeri Malang.

Borg, W.R. \& Gall, M.D. 1983. Educational Research An Introduction. New York \& London: Longman.

Dasmo,dkk. 2017. Pengembangan Pocket Mobile Learning Berbasis Android. Jurnal Riset dan Kajian Pendidikan Fisika. 2017;4(2):71-77 DOI 10.12928/jrkpf.v4i2.7363

De Padua, Pedro H.C, dkk. 2015. Particle Filter-based Predictive Tracking of Futsal Players From a Single Stationary Camera. 28th SIBGRAPI Conference on Graphics, Patterns and Images. 
Dian Ika Purba Ratna Wijayanti Dan B. M. Wara Kushartanti.2014. Model Tes Keterampilan Dasar Futsal Bagi Pemain Ku 10-12 Tahun. Jurnal Keolahragaan. 2014;2(1):32-45

Dwiyogo, W. D. 2010. Dimensi Teknologi Pembelajaran Pendidikan Jasmai\& Olahraga. Malang: Wineka Media.

Iwan Koerniawan dan Siti Kholifah.2016. Pengembangan Aplikasi Mobile Learning Berbasis Kebudayaan Nasional (Bimayana) Untuk Pembelajaran Mata Kuliah Akuntansi Keuangan. Jurnal Informatika Upgris. 2016;2(2) Doi 10.26877/Jiu.V2i2.1251

Muhammad Saefi, dkk. 2017. Developing Android-Based Mobile Learning On Cell Structure And Functions Lesson Subject Topic To Optimize Grade XI Students' Cognitive Comprehension. Jurnal Pendidikan Sains. 2017;5(2):57-63 DOI 10.17977/jps.v5i2.9521

Muhamad Taufik. 2017. Pengembangan Science Mobile Learning Berwawasan Konservasi Berbasis Android App Inventor 2. Usej: Unnes Science Education Journal. 2017;6(1) Doi 10.15294/Usej.V6i1.13179

Ramadhana Agung Pratama, dkk.2018. Mobile Learning Berbasis Game Based Learning Pelajaran Matematika Pokok Bahasan Bangun Ruang Sisi Datar. Jurnal Pendidikan: Teori, Penelitian, dan Pengembangan. 2018;3(6) DOI 10.17977/jptpp.v3i6.11167

Suwasono dan Irawan Dwi S. 2017. Optimasi Akurasi Deteksi Goal Gawang Futsal Dengan Metode Square Grid. Jurnal Pendidikan: Teori, Penelitian, dan Pengembangan. 2017;2(3) DOI 10.17977/jptpp.v2i3.8596

Andryas Yuniarto. Pengembangan Media Pembelajaran Berbasis Mobile Learning Teknik Dasar Dan Peraturan 